\title{
Patterns of dissolved organic carbon and nitrogen fluxes in deciduous and coniferous forests under historic high nitrogen deposition
}

\author{
S. Sleutel ${ }^{1}$, J. Vandenbruwane ${ }^{1}$, A. De Schrijver ${ }^{2}$, K. Wuyts ${ }^{2}$, B. Moeskops ${ }^{1}$, K. Verheyen ${ }^{2}$, and S. De Neve ${ }^{1}$ \\ ${ }^{1}$ Department of Soil Management, Ghent University, Coupure Links 653, 9000 Ghent, Belgium \\ ${ }^{2}$ Laboratory of Forestry, Ghent University, Geraardsbergsesteenweg 267, 9090 Melle, Belgium
}

Received: 5 June 2009 - Published in Biogeosciences Discuss.: 16 July 2009

Revised: 14 October 2009 - Accepted: 29 October 2009 - Published: 1 December 2009

\begin{abstract}
Numerous recent studies have indicated that dissolved organic carbon (DOC) and nitrogen (DON) play an important role in $\mathrm{C}$ and $\mathrm{N}$ cycling in natural ecosystems, and have shown that $\mathrm{N}$ deposition alters the concentrations and fluxes of dissolved organic substances and may increase leaching losses from forests. Our study was set up to accurately quantify concentrations and flux patterns of DOC, DON and dissolved inorganic nitrogen (DIN) in deciduous and coniferous forest in Flanders, Belgium, under historical high nitrogen deposition. We measured DOC, DON and DIN concentrations at two weekly intervals in a silver birch (SB) stand, a corsican pine (CP) stand and a pine stand with higher $\mathrm{N}$ deposition (CPN), and used the SWAP model (calibrated with PEST) for generating accurate water and matter fluxes. The input with precipitation was an important source of DON, but not for DOC. Release of DOC from the forest floor was minimally affected by forest type, but higher $\mathrm{N}$ deposition (CPN stand) caused an $82 \%$ increase of DOC release from the forest floor. Adsorption to mineral soil material rich in iron and/or aluminum oxyhydroxides was suggested to be the most important process removing DOC from the soil solution, responsible for substantial retention (67$84 \%$ ) of DOC entering the mineral soil profile with forest floor leachate. Generally, DON was less reactive (i.e. less removal from the soil solution) than DOC, resulting in decreasing DOC/DON ratios with soil depth. We found increased DOC retention in the mineral soil as a result of higher $\mathrm{N}$ deposition ( $84 \mathrm{~kg} \mathrm{ha}^{-1} \mathrm{yr}^{-1}$ additional DOC retention in CPN compared to $\mathrm{CP}$ ). Overall DON leaching losses were 2.2, 3.3 and $5.0 \mathrm{~kg} \mathrm{Nyr}^{-1}$ for $\mathrm{SB}, \mathrm{CP}$ and $\mathrm{CPN}$, respectively, con-
\end{abstract}

Correspondence to: S. De Neve (stefaan.deneve@ugent.be) tributing between 9-28\% to total dissolved N (TDN) leaching. The relative contribution to TDN leaching from DON loss from SB and CP was mainly determined by (large) differences in DIN leaching. The large TDN leaching losses are alarming, especially in the CPN stand that was $\mathrm{N}$ saturated.

\section{Introduction}

Soil organic matter (SOM) is generally subdivided in two operationally defined fractions, namely solid and dissolved organic matter. Dissolved organic matter (DOM) is operationally defined as the continuum of organic compounds in the dissolved phase passing a filter with a certain pore size (mostly $0.45 \mu \mathrm{m}$ ). Dissolved organic carbon (DOC) and nitrogen (DON) are thus defined as the carbon and nitrogen included in the DOM. The high mobility of DOM results in translocation of organic material and nutrients within and between ecosystems. The downward transport of DOM and associated elements with percolating water also plays a crucial role in soil formation (Zysset and Berggren, 2001), nutrient loss (Kaiser et al., 2001) and eutrophication of ground and surface waters. DOC and DON produced in upland forest soils can leach below the rooting zone and move into aquatic ecosystems (Perakis and Hedin, 2002), where they can influence ecosystem processes.

The principal sources of DOM in water passing through forest ecosystems are release from the forest floor (Michalzik et al., 2001), and to a minor extent release from the canopy and atmospheric deposition (Neff et al., 2002). Adsorption to mineral soil, microbial degradation and leaching to groundwater are considered to be the major sinks or losses of DOM (Kalbitz et al., 2000). The concentrations, and thus fluxes,

Published by Copernicus Publications on behalf of the European Geosciences Union. 
and chemical composition of DOM are related to a large number of external and internal chemical and physical factors (Kalbitz et al., 2000). Precipitation, average temperature (Christ and David, 1996) and the number of drying-rewetting cycles (Prechtel et al., 2000) can be considered to be more or less constant within certain climatic regions. External disturbing influences, mostly as a result of human activities, are much more variable and have been reported to change the chemical composition, concentrations and thus fluxes of DOM. Of these disturbing factors, sulfate deposition (Evans et al., 1988), changes in soil solution ionic strength (Kalbitz et al., 2000) and pH (Vance and David, 1992), and ecosystem nitrogen input (Pregitzer et al., 2004) with throughfall water were found to be the most important.

During the last century, the concentration of nitrogenous compounds in the atmosphere increased as a result of human activities. Combustion of fossil fuels and intensive livestock breeding are probably the two major sources of reactive $\mathrm{N}$ forms in the atmosphere (Galloway et al., 1995). This increased atmospheric nitrogen emission resulted in an elevated wet and dry deposition in aquatic and terrestrial ecosystems, causing changes in biogeochemical cycles (Aber et al., 1989), including cycling of DOM (McDowell et al., 2004).

Contradictory results have been reported concerning the effect of elevated $\mathrm{N}$ deposition on DOM cycling within ecosystems and various mechanisms have been hypothesized and tested. Sjöberg et al. (2003) found no significant changes in DOC and DON production in mor humus after repeated $\mathrm{N}$ additions in a lab experiment. Also Raastad and Mulder (1999) found no significant effects on DOC and DON concentrations after 4 years of nitrogen addition to a forested catchment in Sweden. Currie et al. (1996) found fluxes of DON from the forest floor to be positively correlated with rates of $\mathrm{N}$ addition, but export of DON from the mineral soil appeared unaffected by 7 years of $\mathrm{N}$ amendments. Park et al. (2002) found a reduced DOC release, but increased release of DON and dissolved inorganic nitrogen (DIN) from a deciduous forest floor after $\mathrm{NH}_{4} \mathrm{NO}_{3}$ amendments. Magill et al. (2000) found no effect of nitrogen additions on DOC concentrations, but reported increased DON concentrations in soil water at $60 \mathrm{~cm}$ depth. Pregitzer et al. (2004) reported dramatic increases in leaching losses of DOC and DON during an 8-year $\mathrm{N}$ addition experiment in the field. Also Fang et al. (2008) found very large DON leaching losses in forests under large ambient $\mathrm{N}$ deposition and found that experimental $\mathrm{N}$ additions further increased DON losses in the study forests (Fang et al., 2009).

Despite the important role that is attributed to DOC and DON dynamics and leaching in many ecosystems, relatively few studies have estimated actual fluxes of DOC and DON leaving the soil system. In those studies that estimated annual DOC and DON fluxes, water balances and water fluxes have most often been obtained in a very simple manner. Moreover, the potential impact of increased $\mathrm{N}$ deposition on DOC and DOM cycling in forest ecosystems has mostly been studied in laboratory and field manipulation experiments in which mineral nitrogen forms are artificially added to the ecosystem. However, these manipulation experiments all cover a limited time scale that will often not be sufficient to reach a new equilibrium situation. Finally, DOC and DON fluxes have usually been measured at only one or two ecosystem strata. Therefore, the objective of this study was to accurately quantify concentration and flux patterns of DOC and DON in the different ecosystem strata (bulk deposition, throughfall, and four soil compartments) of a deciduous and coniferous forest on sandy soil in Flanders that had been subjected to high $\mathrm{N}$ depositions for several decades. We also investigated the effect of additional atmospheric $\mathrm{N}$ deposition on DOC and DON dynamics by including a forest edge exposed to the prevailing wind direction. An explicit goal of this study was to quantify the potential effect of forest type and deposition load on the relative contribution of DON in total dissolved $\mathrm{N}$ (TDN) leaching.

\section{Materials and methods}

\subsection{Site description}

This study was conducted in the National Forest Reserve of Ravels, which has a surface area of 800 ha and is located in the northern part of Belgium $\left(51^{\circ} 25^{\prime} \mathrm{N}, 5^{\circ} 04^{\prime} \mathrm{E}\right)$, near Turnhout. The forests in this region are dominated by homogeneous plantations of Corsican pine (Pinus nigra ssp. laricio Maire) and Scots pine (Pinus sylvestris L.), a large part of them in conversion to mixed stands with silver birch (Betula pendula Roth.) and common oak (Quercus robur L.). At the meteorological station of Retie $(16 \mathrm{~km}$ from the research site), mean monthly temperatures vary from $5.5^{\circ} \mathrm{C}$ in January to $19.2^{\circ} \mathrm{C}$ in July. The average annual precipitation in the study area is about $748 \mathrm{~mm}$ and the average annual temperature is $9.5^{\circ} \mathrm{C}$. The study sites were located in a flat area with an elevation of $30 \mathrm{~m}$ above sea level. The region is characterized by intensive livestock breeding and is therefore characterized by high atmospheric concentrations of reduced nitrogen. Three homogenous forest stands were selected. Two neighboring stands, namely one silver birch (SB) and one Corsican pine (CP) stand, were located in the middle of the forest complex "Overheide", part of the state forest "Domeinbos Ravels", both receiving "background" nitrogen deposition. A second Corsican pine stand (CPN) was selected in the forest complex "Tulderse Heide", with an abrupt forest edge bordering undisturbed pasture and exposed to the prevailing westerly to south-westerly winds. The CPN stand was selected because it was expected to have received substantially higher $\mathrm{N}$ depositions compared to the interior parts of closed forest stands (SB and CP). The major stand characteristics for the three forest stands are summarized in Table 1.

The soils under the selected forest stands are podzols developed on sand deposits and classified as Typic Haplorthod 
Table 1. Stand characteristics of the three selected forest stands.

\begin{tabular}{|c|c|c|c|}
\hline Site code & $\begin{array}{l}\text { Silver Birch } \\
\text { (SB) }\end{array}$ & $\begin{array}{l}\text { Corsican Pine } \\
(\mathrm{CP})\end{array}$ & $\begin{array}{l}\text { High Deposition } \\
\text { Corsican Pine (CPN) }\end{array}$ \\
\hline Location name & Overheide & Overheide & Tulderse Heide \\
\hline Longitude & $51^{\circ} 25^{\prime} 27.0^{\prime \prime} \mathrm{N}$ & $51^{\circ} 25^{\prime} 28.6^{\prime \prime} \mathrm{N}$ & $51^{\circ} 26^{\prime} 11.7^{\prime \prime} \mathrm{N}$ \\
\hline Latitude & $5^{\circ} 03^{\prime} 20.7^{\prime \prime} \mathrm{E}$ & $5^{\circ} 03^{\prime} 21.3^{\prime \prime} \mathrm{E}$ & $5^{\circ} 05^{\prime} 26.5^{\prime \prime} \mathrm{E}$ \\
\hline Elevation (m a.s.1.) & 27.4 & 27.4 & 28.9 \\
\hline Tree species & $\begin{array}{l}\text { Betula pendula } \\
\text { Roth }\end{array}$ & $\begin{array}{l}\text { Pinus nigra ssp. } \\
\text { Laricio Maire }\end{array}$ & $\begin{array}{l}\text { Pinus nigra ssp. } \\
\text { Laricio Maire }\end{array}$ \\
\hline $\operatorname{Age}^{*}(y r)$ & 45 & 50 & 45 \\
\hline Stand density* (number ha ${ }^{-1}$ ) & 891 & 722 & $\mathrm{nd}^{\dagger}$ \\
\hline Average tree height* $(\mathrm{m})$ & 17.4 & 17.2 & 15.4 \\
\hline Basal area* $\left(\mathrm{m}^{2} \mathrm{ha}^{-1}\right)$ & 21 & 41 & nd \\
\hline Average $\mathrm{LAI}^{*}\left(\mathrm{~m}^{2} \mathrm{~m}^{-2}\right)$ & 2.67 & 2.86 & 2.50 \\
\hline Current volume growth $\left(\mathrm{m}^{3} \mathrm{ha}^{-1} \mathrm{yr}^{-1}\right)^{*}$ & 0.67 & 1.38 & 1.50 \\
\hline Distance to W-NW forest edge (m) & 435 & 435 & $<10$ \\
\hline
\end{tabular}

\footnotetext{
* Results from complete stand survey in 2006;

${ }^{\dagger}$ nd = not determined;

$\ddagger$ data deducted from Jansen et al. (1996).
}

according to USDA Soil Taxonomy. Composite soil samples (15 augerings per composite sample) were airdried and homogenized, sieved over a $2 \mathrm{~mm}$ mesh and analysed for important general soil properties (Table 2). The $\mathrm{pH}$ was measured potentiometrically in a $1 / 2.5 \mathrm{soil} / 1 \mathrm{M} \mathrm{KCl}$ extract $(\mathrm{pH}-$ $\mathrm{KCl})$ and in a $1 / 5$ soil/water extract $\left(\mathrm{pH}-\mathrm{H}_{2} \mathrm{O}\right)$. Total carbon $\left(\mathrm{C}_{\text {tot }}\right)$ and total nitrogen $\left(\mathrm{N}_{\text {tot }}\right)$ were measured by dry combustion at $850^{\circ} \mathrm{C}$ using an elemental analyzer (Vario MAX CNS, Elementar, Germany). The $\mathrm{NH}_{4}^{+}$-acetate method was used to determine the cation-exchange capacity (CEC) of the soils. Particle-size distribution was determined by the pipette method. Ammonium oxalate-extractable iron and aluminum $\left(\mathrm{Fe}_{\mathrm{ox}}\right.$ and $\left.\mathrm{Al}_{\mathrm{Ox}}\right)$ was extracted using the method of Jackson et al. (1986) and then measured with an atomic absorption spectrophotometer (SpectrAA, Varian, Belgium).

The forest floor of the three forest stands consisted of a succession of Oi, Oe and Oa layers, with a sharp boundary between the $\mathrm{Oa}$ and mineral A horizon. Consequently the forest floors were classified as mor humus types. The thickness of the forest floor (Oi+Oe+Oa) was 5,3 and $2 \mathrm{~cm}$ in the $\mathrm{SB}, \mathrm{CP}$ and CPN stands, respectively. Forest floor material (Oi+Oe+Oa) from a $0.25 \mathrm{~m}^{2}$ square was completely sampled in 9 replicates at each of the three forest stands and weighed under field moist conditions. Subsamples of these homogenized samples were taken for chemical analyses. Portions of these subsamples were dried at $60^{\circ} \mathrm{C}$ for $96 \mathrm{~h}$ to determine moisture content and the amount of dry forest floor material per $\mathrm{m}^{2}$ was calculated. The dried subsamples were ground using a ball-mill and stored in glass vials until further chemical analyses (Table 3).

\subsection{Experimental set-up and sample collection}

Litterfall in the three forest stands was collected in 9 replicates using round collection baskets $\left(0.25 \mathrm{~m}^{2}\right)$ equipped with nylon wire netting at $60 \mathrm{~cm}$ above the soil surface for 1 year. An inert PVC weight was used to prevent the samples to be blown over the edge of the basket. Samples were collected monthly and dried at $60^{\circ} \mathrm{C}$ for dry matter determination. The dried samples from each collection basket were then bulked per location and ground for further chemical analyses.

Within each of the forest stands, three replicate plots of about $20 \mathrm{~m}^{2}$ each and spaced about $10 \mathrm{~m}$ apart were established to monitor the amount and composition of throughfall water, forest floor leachate, soil solution and groundwater. In SB and CP, the plots were installed in the middle of the stands to avoid edge influences, while in CPN, plots were installed within the first $10 \mathrm{~m}$ from the exposed forest edge. Water samples were collected and measured fortnightly between March 2005 and March 2006. The three replicate plots within the each of the three forest stands can be considered as pseudo-replicates, and not as completely independent replicates. However, this choice of replication was the only manner to have the replicates within these three forest stands on one homogenous soil type.

Open-field bulk deposition was collected in grassland (for $\mathrm{SB}$ and $\mathrm{CP}$ ) or a recently afforested clear-cut (for CPN) in the immediate surroundings of the stands using four collectors. In each forested plot, four throughfall collectors were installed spaced $2 \mathrm{~m}$ apart (arranged in a square position). Stemflow was not collected because of its negligible contribution to the total ion flux reaching the forest floor in pine stands. For silver birch, its contribution to the total water 
Table 2. Mineral soil properties to a depth of $90 \mathrm{~cm}$ at the three sites under investigation (SB: silver birch, CP: Corsican pine, CPN: high deposition Corsican pine).

\begin{tabular}{|c|c|c|c|c|c|c|c|c|c|}
\hline & $\begin{array}{r}\text { Thickness } \\
\text { (cm) }\end{array}$ & $\begin{array}{r}\mathrm{pH}-\mathrm{H}_{2} \mathrm{O} \\
(-)\end{array}$ & $\begin{array}{r}\mathrm{pH}-\mathrm{KCl} \\
(-)\end{array}$ & $\begin{array}{r}\mathrm{C} \\
(\%)\end{array}$ & $\begin{array}{r}\text { Sand } \\
(2000-50 \mu \mathrm{m}) \\
(\%)\end{array}$ & $\begin{array}{r}\text { Silt } \\
(50-2 \mu \mathrm{m}) \\
(\%)\end{array}$ & $\begin{array}{r}\text { Clay } \\
(<2 \mu \mathrm{m}) \\
(\%)\end{array}$ & $\begin{array}{r}\mathrm{Fe}_{\mathrm{ox}} \\
\left(\mathrm{g} \mathrm{kg}^{-1}\right)\end{array}$ & $\begin{array}{r}\mathrm{Al}_{\mathrm{OX}} \\
\left(\mathrm{g} \mathrm{kg}^{-1}\right)\end{array}$ \\
\hline \multicolumn{10}{|l|}{ SB } \\
\hline A & $12 \pm 1$ & $4.18 \pm 0.02$ & $2.82 \pm 0.01$ & $3.96 \pm 0.08$ & 92.5 & 6.9 & 0.5 & $0.38 \pm 0.04$ & $0.37 \pm 0.01$ \\
\hline $\mathrm{E}$ & $5 \pm 0$ & $4.28 \pm 0.05$ & $3.14 \pm 0.05$ & $1.25 \pm 0.00$ & 93.5 & 5.9 & 0.6 & $0.15 \pm 0.02$ & $0.18 \pm 0.02$ \\
\hline $\mathrm{Bh}$ & $4 \pm 1$ & $4.01 \pm 0.00$ & $3.09 \pm 0.06$ & $6.34 \pm 0.01$ & 92.2 & 6.4 & 1.4 & $1.43 \pm 0.03$ & $2.02 \pm 0.02$ \\
\hline $\mathrm{Bs}$ & $7 \pm 0$ & $4.38 \pm 0.01$ & $4.08 \pm 0.03$ & $1.52 \pm 0.02$ & 93.1 & 5.2 & 1.7 & $4.09 \pm 0.04$ & $1.72 \pm 0.01$ \\
\hline $\mathrm{BC}$ & $30 \pm 1$ & $4.70 \pm 0.01$ & $4.63 \pm 0.02$ & $0.33 \pm 0.01$ & 94.3 & 3.8 & 1.9 & $1.63 \pm 0.05$ & $1.51 \pm 0.04$ \\
\hline $\mathrm{C}$ & $32 \pm 2$ & $4.78 \pm 0.01$ & $4.58 \pm 0.08$ & $0.17 \pm 0.01$ & 96.2 & 2.6 & 1.2 & $0.74 \pm 0.03$ & $0.84 \pm 0.03$ \\
\hline \multicolumn{10}{|l|}{$\mathrm{CP}$} \\
\hline A & $17 \pm 3$ & $4.31 \pm 0.07$ & $2.99 \pm 0.03$ & $4.15 \pm 0.02$ & 93.3 & 5.8 & 0.9 & $0.55 \pm 0.05$ & $0.86 \pm 0.04$ \\
\hline $\mathrm{E}$ & $13 \pm 1$ & $4.53 \pm 0.02$ & $3.75 \pm 0.02$ & $0.56 \pm 0.02$ & 95.1 & 4.7 & 0.2 & $0.11 \pm 0.00$ & $0.18 \pm 0.01$ \\
\hline $\mathrm{Bh}$ & $7 \pm 3$ & $4.18 \pm 0.03$ & $3.61 \pm 0.04$ & $3.17 \pm 0.06$ & 93.9 & 4.4 & 1.7 & $0.45 \pm 0.02$ & $1.44 \pm 0.01$ \\
\hline $\mathrm{Bs}$ & $7 \pm 2$ & $4.18 \pm 0.00$ & $3.72 \pm 0.06$ & $2.98 \pm 0.06$ & 93.5 & 4.7 & 1.8 & $0.55 \pm 0.04$ & $2.03 \pm 0.09$ \\
\hline $\mathrm{BC}$ & $17 \pm 2$ & $4.53 \pm 0.03$ & $4.52 \pm 0.10$ & $0.52 \pm 0.02$ & 94.4 & 4.5 & 1.1 & $0.80 \pm 0.03$ & $1.83 \pm 0.05$ \\
\hline $\mathrm{C}$ & $29 \pm 2$ & $4.58 \pm 0.02$ & $4.59 \pm 0.05$ & $0.18 \pm 0.08$ & 94.4 & 4.7 & 0.8 & $0.28 \pm 0.01$ & $0.82 \pm 0.01$ \\
\hline \multicolumn{10}{|c|}{$\mathrm{CPN}$} \\
\hline A & $17 \pm 3$ & $4.26 \pm 0.04$ & $2.83 \pm 0.05$ & $3.10 \pm 0.23$ & 95.7 & 4.3 & 0.1 & $0.26 \pm 0.00$ & $0.20 \pm 0.01$ \\
\hline $\mathrm{E}$ & $12 \pm 5$ & $4.31 \pm 0.02$ & $3.17 \pm 0.01$ & $0.93 \pm 0.01$ & 95.7 & 4.2 & 0.1 & $0.10 \pm 0.02$ & $0.08 \pm 0.01$ \\
\hline $\mathrm{Bh}$ & $13 \pm 3$ & $3.91 \pm 0.02$ & $3.09 \pm 0.03$ & $2.77 \pm 0.01$ & 94.2 & 4.5 & 1.3 & $0.25 \pm 0.03$ & $1.12 \pm 0.02$ \\
\hline Bs & $9 \pm 5$ & $4.08 \pm 0.01$ & $3.40 \pm 0.01$ & $1.44 \pm 0.02$ & 94.9 & 3.6 & 1.5 & $0.26 \pm 0.02$ & $1.24 \pm 0.02$ \\
\hline $\mathrm{BC}$ & $22 \pm 2$ & $4.51 \pm 0.00$ & $4.15 \pm 0.05$ & $0.35 \pm 0.02$ & 98.6 & 0.9 & 0.5 & $0.37 \pm 0.12$ & $1.58 \pm 0.06$ \\
\hline $\mathrm{C}$ & $17 \pm 3$ & $4.68 \pm 0.01$ & $4.54 \pm 0.05$ & $0.18 \pm 0.00$ & 98.9 & 0.9 & 0.2 & $0.14 \pm 0.01$ & $0.06 \pm 0.01$ \\
\hline
\end{tabular}

Table 3. Main properties of forest floor material and annual litterfall at the three selected forest stands.

\begin{tabular}{lrrr}
\hline & $\begin{array}{r}\text { Silver Birch } \\
(\mathrm{SB})\end{array}$ & $\begin{array}{r}\text { Corsican Pine } \\
(\mathrm{CP})\end{array}$ & $\begin{array}{r}\text { High Deposition Corsican Pine } \\
(\mathrm{CPN})\end{array}$ \\
\hline Forest floor & & & \\
Dry matter (DM) $\left(\mathrm{kg} \mathrm{m}^{-2}\right)$ & $5.80 \pm 1.50^{\mathrm{a}}$ & $5.30 \pm 1.36^{\mathrm{a}}$ & $4.00 \pm 0.50^{\mathrm{b}}$ \\
Ash (\%) & $14.9 \pm 14.7^{\mathrm{a}}$ & $19.8 \pm 10.4^{\mathrm{a}}$ & $27.4 \pm 12.9^{\mathrm{a}}$ \\
$\mathrm{C}_{\text {tot }}(\%)$ & $48.4 \pm 4.1^{\mathrm{a}}$ & $45.8 \pm 4.0^{\mathrm{a}}$ & $43.7 \pm 1.4^{\mathrm{a}}$ \\
$\mathrm{N}_{\text {tot }}(\%)$ & $2.24 \pm 0.23^{\mathrm{a}}$ & $1.70 \pm 0.32^{\mathrm{b}}$ & $1.61 \pm 0.33^{\mathrm{b}}$ \\
$\mathrm{C} / \mathrm{N}$ & $21.6 \pm 0.5^{\mathrm{a}}$ & $27.0 \pm 3.1^{\mathrm{b}}$ & $27.2 \pm 3.5^{\mathrm{b}}$ \\
$\mathrm{pH}-\mathrm{H}_{2} \mathrm{O}$ & $3.79 \pm 0.02^{\mathrm{a}}$ & $3.80 \pm 0.03^{\mathrm{a}}$ & $4.02 \pm 0.01^{\mathrm{b}}$ \\
Annual litterfall & & & \\
Dry matter $\left(\mathrm{kg} \mathrm{m}^{-2} \mathrm{yr}^{-1}\right)$ & $0.37 \pm 0.02^{\mathrm{a}}$ & $0.82 \pm 0.10^{\mathrm{b}}$ & $0.56 \pm 0.13^{\mathrm{a}}$ \\
$\mathrm{C}_{\text {tot }}(\%)$ & $50.5 \pm 0.1^{\mathrm{a}}$ & $49.4 \pm 0.5^{\mathrm{b}}$ & $49.6 \pm 0.6^{\mathrm{b}}$ \\
$\mathrm{N}_{\text {tot }}(\%)$ & $1.56 \pm 0.05^{\mathrm{a}}$ & $0.82 \pm 0.11^{\mathrm{b}}$ & $1.07 \pm 0.10^{\mathrm{a}}$ \\
$\mathrm{C} / \mathrm{N}$ & $32.4 \pm 1.1^{\mathrm{a}}$ & $60.2 \pm 12.2^{\mathrm{b}}$ & $46.4 \pm 8.9^{\mathrm{b}}$ \\
\hline
\end{tabular}

a,b Means with a different letter within the same line differ significantly at the $p<0.05$ level.

flux and $\mathrm{N}$ flux to the forest floor is generally limited to 2 and $1 \%$, respectively (Alcock and Morton, 1985). Throughfall and precipitation water were collected using polyethylene funnels $\left(177 \mathrm{~cm}^{2}\right)$ supported by and draining into twoliter polyethylene bottles. The bottles were placed below ground level to keep the samples cool and to protect them from direct sunlight. The use of a nylon wire mesh placed in the funnel prevented contamination by large particles. At each sampling occasion, the sample volume in every collection bottle was measured on site and PE bottles and funnels were replaced by specimens that were rinsed with distilled water. Samples with visible contamination of animal excreta 
were discarded, and the remaining samples of each plot were pooled volume-weighted to one bulk sample. A $300 \mathrm{ml}$ subsample was then taken for chemical analysis.

The forest floor leachate was collected using three zerotension lysimeters per plot, installed directly underneath the forest floor. These lysimeters were made from $30 \mathrm{~cm}$ long rectilinear polyvinylchloride (PVC) guttering $\left(338 \mathrm{~cm}^{2}\right)$ covered with wire netting $(1.5 \mathrm{~mm}$ mesh size) and connected with $20 \mathrm{~cm}$ flexible PVC tubing to a two-liter PE bottle installed beneath the lysimeter. At every sampling event, the three forest floor leachate samples of each plot were pooled volume-weighted to one bulk sample and the PE sampling bottles were replaced by collectors that were rinsed with distilled water.

The soil solution in the different horizons was sampled using acid washed ceramic suction cup lysimeters (Model 1900 Soil Water Sampler with B02M2 cup, Soilmoisture Equipment Corp., Santa Barbara, USA). A preliminary experiment indicated that these lysimeters have least influence on the sampled DOC concentration compared to other types (Vandenbruwane, 2008). Per plot (three replicate plots per site), a lysimeter was installed at each of three depths $(15,25$ and $65 \mathrm{~cm}$, corresponding approximately to the bottom of the $\mathrm{E}$, Bs and $\mathrm{BC}$ horizon) to sample the percolating water. The applied suction was $-50 \mathrm{kPa}$. The lysimeters were installed 6 months before the start of the monitoring program and on average 3.21 of soil solution was sampled by each lysimeter in order to bring them in equilibrium with the surrounding soil (solution) before the effective start of the sample collection. No water could be extracted from the ceramic cups in the CP plots between mid September and the end of November.

For groundwater sampling, perforated PVC tubes $(4 \mathrm{~cm}$ diameter) equipped with $\mathrm{PE}$ tubing to the bottom, were installed to a depth of $2.5 \mathrm{~m}$ in the mineral soil. At every sampling event, the depth of the groundwater table was measured using an electronic water level meter and the sampling tube was evacuated three times before effective sampling. The groundwater was pumped up through PE tubing draining into a Büchner flask which was connected to a vacuum pump.

The matric potential in the mineral soil of the SB and CP stand was monitored continuously using electronic tensiometers (T4, UMS GmbH, München, Germany) connected to a datalogger (DL2e, Delta-T Devices Ltd., Cambridge, UK), equipped with an external $12 \mathrm{~V}$ power supply (TV-Batt, UMS $\mathrm{GmbH}$, München, Germany). Tensiometers were installed at three depths $(15,25$ and $65 \mathrm{~cm})$ in the three replicate plots of the SB and CP stands only, and the matric potentials were recorded at hourly intervals. For purposes of model calibration (Appendix A), the moisture content of the soil at these depths was determined gravimetrically at four occasions and converted to volumetric moisture content using the bulk densities measured on intact soil cores.

Soil temperature at different depths in the soil profile $(15,25,65$ and $90 \mathrm{~cm})$ was recorded in one SB plot on an hourly base using electronic temperature probes with Fenwall-thermistor (Th2-f, UMS GmbH, München, Germany) connected to a datalogger (DL2e, Delta-T Devices Ltd, Cambridge, UK) equipped with an external $12 \mathrm{~V}$ power supply (TV-Batt, UMS GmbH, München, Germany).

\subsection{Chemical analyses}

Before analysis, all samples were filtered through $0.45 \mu \mathrm{m}$ nylon syringe filters (Rotilab®, Carl Roth $\mathrm{GmbH}$, Karlsruhe, Germany) and kept at $-18^{\circ} \mathrm{C}$ until analysis. All samples were analyzed for DOC, TDN, $\mathrm{NO}_{3}^{-}$and $\mathrm{NH}_{4}^{+}$concentration. Total dissolved carbon (TDC) and dissolved inorganic carbon (DIC) were determined on a Shimadzu TOC-V CPNanalyzer (Shimadzu Corp., Tokyo, Japan) with IR detection following thermal oxidation. Dissolved organic carbon (DOC) was calculated as the difference between TDC and DIC. Total dissolved nitrogen (TDN) was determined after alkaline persulfate oxidation (Koroleff, 1983) as $\mathrm{NO}_{3}^{-}$with a continuous flow autoanalyser. Samples were analyzed for dissolved inorganic nitrogen (DIN) $\left(\left(\mathrm{NO}_{3}^{-}+\mathrm{NO}_{2}^{-}\right)-\mathrm{N}\right.$ and $\mathrm{NH}_{4}^{+}-\mathrm{N}$ ) using a continuous flow autoanalyser (ChemLab System 4) and dissolved organic nitrogen (DON) was calculated as the difference between TDN and DIN. A substantial subset of samples with various concentrations and origins, were analyzed for $\mathrm{NO}_{2}^{-}-\mathrm{N}$, but none were above the detection limit. Detection limits for nitrate-N and ammonium-N were 0.21 and $0.03 \mathrm{mg} \mathrm{N}^{-1}$ respectively, whereas the $95 \%$ confidence interval (CI) and thus detection limit of the DON determinations was variable and depended on the DIN/TDN ratio (Vandenbruwane et al., 2007a).

\subsection{Calculation of solute fluxes}

Water fluxes of precipitation and throughfall were measured on site fortnightly. The water fluxes through the forest floor and mineral soil at different depths in the three forest stands were calculated using the mechanistic water-balance model SWAP (Table 4). Detail on these simulations is provided in Appendix A. Fortnightly solute fluxes were then calculated by multiplying the fortnightly water fluxes by the fortnightly solute concentrations. These solute fluxes where then summed to yield the annual solute flux for each stratum. For the period mid September - end November where no water could be extracted from the ceramic cups in the CP plots, interpolated values between the neighbouring sampling times were used.

\subsection{Statistical analyses}

One way ANOVA was used to detect significant differences in throughfall DOC, DON and DIN concentrations between the three forest stands. Independent samples t-tests were used to detect significant differences in precipitation, DOC, DON and DIN concentrations between the two open field 
Table 4. Water fluxes $\left(\mathrm{mm} \mathrm{yr}^{-1}\right)$ in the different strata of the three forest stands.

\begin{tabular}{lrrr}
\hline Stratum & $\begin{array}{r}\text { Silver } \\
\text { Birch (SB) }\end{array}$ & $\begin{array}{r}\text { Corsican } \\
\text { Pine (CP) }\end{array}$ & $\begin{array}{r}\text { High Deposition } \\
\text { Corsican } \\
\text { Pine (CPN) }\end{array}$ \\
\hline Precipitation $^{\mathrm{a}}$ & 784 & 784 & 792 \\
Throughfall $^{\mathrm{a}}$ & 654 & 569 & 504 \\
Humus percolate $^{\mathrm{b}}$ & 649 & 564 & 497 \\
E-horizon $^{\mathrm{b}}$ & 468 & 420 & 423 \\
Bh-horizon $^{\mathrm{b}}$ & 376 & 358 & 368 \\
BC-horizon $^{\mathrm{b}}$ & 281 & 210 & 224 \\
Groundwater depth $^{\mathrm{c}}$ & 182 & 209 & 213 \\
\hline
\end{tabular}

a Results from the actual measured volumes at the site.

$\mathrm{b}$ Results from the SWAP model calculations.

c Average groundwater depth measured in field $(\mathrm{cm})$.

bulk deposition collectors (SB and CP) and (CPN). Correlations between DOC and DON concentrations in forest floor leachates of each of the three stands and in the three mineral horizons of the three stands together were analysed by linear regression analysis. The significance of the linear regressions was assessed using ANOVA. All statistical analyses were performed using SPSS 12.0. Since the solute fluxes result from the combination of measured concentrations with simulations of water fluxes with the SWAP model, the replicated outcomes of the flux calculations do not allow for a rigorous statistical analysis. However, an exhaustive error propagation analysis using Monte Carlo techniques, which would be appropriate in this case, was outside of the scope of this study.

\section{Results}

\subsection{Nitrogen deposition}

The bulk DIN deposition in precipitation at the Overheide (SB and $\mathrm{CP}$ ) and Tulderse Heide site (CPN) (14.2 $\mathrm{kg} \mathrm{DIN} \mathrm{ha}^{-1} \mathrm{yr}^{-1}$ and $16.4 \mathrm{~kg} \mathrm{DIN} \mathrm{ha}^{-1} \mathrm{yr}^{-1}$, respectively) were not significantly $(p>0.05)$ different (Fig. 1), and neither was the DON deposition (6.4 $\mathrm{kg} \mathrm{DON} \mathrm{ha}^{-1} \mathrm{yr}^{-1}$ and $7.1 \mathrm{~kg} \mathrm{DON} \mathrm{ha}^{-1} \mathrm{yr}^{-1}$, respectively). As a result, the bulk TDN deposition with precipitation only differed about $3 \mathrm{~kg} \mathrm{Nha}^{-1} \mathrm{yr}^{-1}$ between the two sites, and this difference was not significant. Thus, DIN contributed for about $70 \%$ to the TDN deposition in this region and was mainly in the form of ammonium-N (65\% of DIN) (Table 5).

The DIN and DON throughfall fluxes differed between the two neighbouring stands; 19.1 and $5.4 \mathrm{~kg} \mathrm{~N} \mathrm{ha}^{-1} \mathrm{yr}^{-1}$ in the SB stand and 30.8 and $6.3 \mathrm{~kg} \mathrm{Nha}^{-1} \mathrm{yr}^{-1}$ in the adjacent CP stand, but according to Duncan's MRT posthoc test this difference was not significant. The DIN and DON throughfall fluxes in the CPN plots of 37.8 and
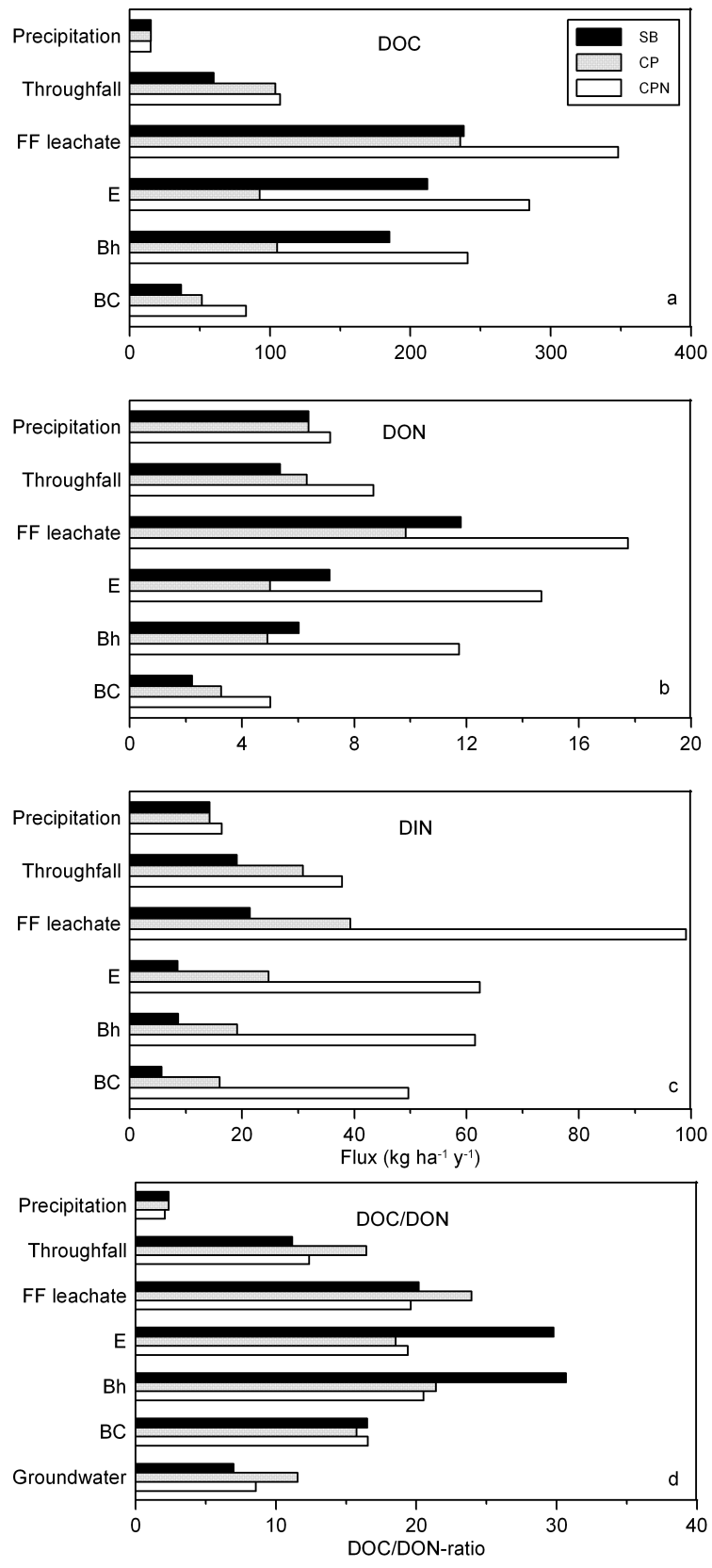

Fig. 1. Annual fluxes of dissolved organic carbon (DOC) (a), nitrogen (DON) (b) and dissolved inorganic nitrogen (DIN) (c) and DOC/DON-ratio (d) in the different strata of the three forest stands (SB: silver birch, CP: Corsican pine, CPN: high deposition Corsican pine).

$8.7 \mathrm{~kg} \mathrm{Nha}^{-1} \mathrm{yr}^{-1}$ respectively, were significantly higher $(p<0.01)$ than in the SB and CP plots. The difference in total nitrogen input with throughfall water between the two deposition loads was $9.4 \mathrm{~kg} \mathrm{~N} \mathrm{ha}^{-1} \mathrm{yr}^{-1}$ in total $(7.0 \mathrm{~kg}$ DIN and $2.4 \mathrm{~kg} \mathrm{DON} \mathrm{ha}^{-1} \mathrm{yr}^{-1}$ ) or an increase of about $25 \%$. Our experimental set-up with (pseudo) replicates within single forest stands may have resulted in increased type I errors in the 
Table 5. Average TDN composition (as \% of TDN) in the different strata of the three forest ecosystems over the 1 year sampling period.

\begin{tabular}{lccccccccc}
\hline Stratum & \multicolumn{3}{c}{$\begin{array}{c}\text { Silver Birch } \\
\text { (SB) }\end{array}$} & \multicolumn{3}{c}{$\begin{array}{c}\text { Corsican Pine } \\
(\mathrm{CP})\end{array}$} & \multicolumn{4}{c}{$\begin{array}{c}\text { High Deposition Corsican } \\
\text { Pine (CPN) }\end{array}$} \\
& $\mathrm{NO}_{3}^{-}-\mathrm{N}$ & $\mathrm{NH}_{4}^{+}-\mathrm{N}$ & $\mathrm{DON}^{-}$ & $\mathrm{NO}_{3}^{-}-\mathrm{N}$ & $\mathrm{NH}_{4}^{+}-\mathrm{N}$ & $\mathrm{DON}$ & $\mathrm{NO}_{3}^{-}-\mathrm{N}$ & $\mathrm{NH}_{4}^{+}-\mathrm{N}$ & DON \\
\hline Precipitation & 24 & 45 & 31 & 24 & 45 & 31 & 24 & 46 & 30 \\
Throughfall & 23 & 55 & 22 & 21 & 62 & 17 & 21 & 61 & 19 \\
Forest floor & 45 & 19 & 35 & 50 & 30 & 20 & 33 & 52 & 15 \\
E-horizon & 50 & 4 & 46 & 77 & 7 & 17 & 55 & 26 & 19 \\
Bh-horizon & 56 & 3 & 41 & 78 & 2 & 20 & 61 & 23 & 16 \\
BC-horizon & 67 & 5 & 28 & 81 & 2 & 17 & 90 & 1 & 9 \\
Groundwater & 83 & 3 & 14 & 88 & 1 & 11 & 93 & 1 & 6 \\
\hline
\end{tabular}

ANOVA, and hence significant differences reported above must be interpreted with caution.

\subsection{Temporal concentration patterns of DOC and DON}

The DOC concentrations sampled below the forest floor showed a very similar pattern (largest concentrations in autumn) at the SB and CP sites, whereas a different pattern (little seasonal flucturations) and higher concentrations were found at the CPN site. The course of the DOC concentrations in the forest floor leachate was influenced by the water fluxes during the sampled fortnight and the preceding fortnight(s) (Fig. 2). For instance, considering the three dry fortnights in late May and June followed by a high water flux at the beginning of July, the DOC concentrations in the litter leachate increased steadily during the dryer weeks i.e. accumulation of leachable DOM occurred in the forest floor during dryer periods. This accumulation effect for DOC was also observed on 27 July, 26 October and 22 December. The inverse effect i.e. dilution as a result of a higher water flux occurred on 10 August, 9 December and 23 February. In the SB and CP stands, lower DOC concentrations were observed with increasing soil temperature, whereas higher temperatures tended to increase DOC release from the forest floor material in the CPN stand.

The DON concentrations below the forest floor material exhibited no clear seasonal pattern in the SB and CP stands. DON concentrations tended to be larger in the CPN stand (but not significantly), and the largest concentrations were observed in summer and early autumn. Positive correlations between DOC and DON concentrations were found in the forest floor leachates of the SB and CP stands $(r=0.461$, $p=0.063$ and $r=0.775, p=0.013$, respectively). However, there was no correlation $(p=0.481)$ between DOC and DON concentrations in the forest floor leachate of the CPN stand.

More or less constant DOC concentrations were measured below the $\mathrm{BC}$ horizon throughout the year at all sites, with limited seasonal fluctuations (Fig. 3). The restricted DOC fluctuations in the lower part of the soil profile compared to the larger variations in DOC concentrations entering the min- eral soil suggest the presence of a mechanism controlling the DOC concentrations in the mineral soil.

The DON concentration below the BC horizon exhibited no clear seasonal pattern, and in general flucuations were larger than for DOC, especially in the CPN stand. DON concentrations in the CPN stand tended to be largest in spring and summer.

\subsection{Annual fluxes in the ecosystem strata}

The DOC flux in precipitation water measured in our study was $15 \mathrm{~kg} \mathrm{ha}^{-1} \mathrm{yr}^{-1}$ at both sites (Fig. 1a). Passage of precipitation water through the $\mathrm{SB}, \mathrm{CP}$ and $\mathrm{CPN}$ canopies added 45,89 and $92 \mathrm{~kg} \mathrm{DOC} \mathrm{ha}^{-1} \mathrm{yr}^{-1}$, respectively, to the throughfall water flux (Table 6).

The forest floor was by far the major source of DOC in these ecosystems (Table 6). Average DOC fluxes under the forest floor in the SB, CP and CPN were 236, 238 and $348 \mathrm{~kg} \mathrm{ha}^{-1} \mathrm{yr}^{-1}$, respectively. Fluxes of DOC decreased consistently with depth in the mineral soil, though the major DOC retention took place at different depths: in SB and CPN most DOC $\left(148 \mathrm{~kg} \mathrm{ha}^{-1} \mathrm{yr}^{-1}\right)$ was removed between the lower boundaries of the $\mathrm{Bh}$ and $\mathrm{BC}$ horizons, while in $\mathrm{CP}$ more DOC removal occurred in the upper horizons. The DOC fluxes leaching below the $\mathrm{BC}$ horizon ranged from $37 \mathrm{~kg} \mathrm{ha}^{-1} \mathrm{yr}^{-1}$ in the SB stand over $51 \mathrm{~kg} \mathrm{ha}^{-1} \mathrm{yr}^{-1}$ in the $\mathrm{CP}$ stand to $83 \mathrm{~kg} \mathrm{ha}^{-1} \mathrm{yr}^{-1}$ in the CPN stand (Fig. 1a), suggesting an influence of both tree species (SB versus $\mathrm{CP}$ ) and forest edge proximity (CP versus $\mathrm{CPN}$ ). Overall, the mineral soil profile of the SB, CP and CPN stand retained 201, 185 and $265 \mathrm{~kg} \mathrm{DOC} \mathrm{ha}^{-1} \mathrm{yr}^{-1}$ respectively or 84,79 and $76 \%$ of the DOC entering the mineral soil with forest floor leachate respectively. Average groundwater DOC concentrations were low and relatively constant throughout the year at the three sites, i.e. a similar pattern as the DOC concentrations under the BC-horizons (data not shown). However, the DOC concentrations in the groundwater were only 24 $29 \%$ of the DOC concentration at $65 \mathrm{~cm}$, suggesting that further important DOC removal processes must be active in the deeper mineral soil (parent material). 
Table 6. Net addition (indicated by a + sign) or removal (indicated by a - sign) $\left(\mathrm{kg} \mathrm{ha}^{-1} \mathrm{yr}^{-1}\right)$ of DOC, DON, and DIN from solution as it passed through each stratum or horizon. Calculated as: the flux through the stratum minus the flux through the stratum above.

\begin{tabular}{lccccccccc}
\hline Stratum & \multicolumn{3}{c}{$\begin{array}{c}\text { Silver Birch } \\
\text { (SB) }\end{array}$} & \multicolumn{3}{c}{ Corsican Pine } & \multicolumn{3}{c}{ High Deposition Corsican } \\
& DOC & DON & DIN & DOC & DON & DIN & DOC & DON & DIN \\
\hline Throughfall & 45 & -1.01 & 4.84 & 89 & -0.06 & 16.6 & 92 & 1.54 & 21.4 \\
Forest floor & 178 & 6.43 & 2.37 & 132 & 3.52 & 8.48 & 240 & 9.07 & 61.3 \\
E-horizon & -26 & -4.67 & -12.9 & -143 & -4.84 & -14.6 & -63 & -3.08 & -36.7 \\
Bh-horizon & -27 & -1.09 & 0.12 & 12 & -0.10 & -5.57 & -44 & -2.93 & -0.87 \\
BC-horizon & -148 & -3.81 & -2.94 & -54 & -1.63 & -3.15 & -158 & -6.73 & -11.87 \\
\hline
\end{tabular}

Similar as for DOC, the forest floor was the largest source of DON in the three forest stands releasing 6.4, 3.5 and $9.1 \mathrm{~kg} \mathrm{ha}^{-1} \mathrm{yr}^{-1}$ in the SB, CP and CPN stand respectively (Table 6), suggesting an effect of forest edge proximity on the release of DON from the forest floor. The total amount of DON retained by the mineral soil of the SB, CP and CPN stand was 9.6, 6.6 and $12.7 \mathrm{~kg} \mathrm{ha}^{-1} \mathrm{yr}^{-1}$ or 81,67 and $72 \%$ of the DON entering the mineral soil, respectively. The annual DON fluxes leaving the rooting zone of these forest ecosystems were $2.2,3.3$ and $5.0 \mathrm{~kg} \mathrm{ha}^{-1} \mathrm{yr}^{-1}$ in the $\mathrm{SB}, \mathrm{CP}$ and CPN stand respectively (Fig. 1b). The DON concentrations further decreased by an additional 23, 14 and $32 \%$ between the lower boundary of the $\mathrm{BC}$ horizon and the groundwater in the SB, CP and CPN stand, respectively. Thus, further DON removal processes are active in the deeper mineral soil, but retention was less intensive than for DOC.

\subsection{Relationship between DON and DOC}

The DON concentrations in the forest floor of SB and CP stands and in the different mineral soil compartments of the three forest stands were positively correlated with the measured DOC concentrations. We found an average DOC/DON ratio in the mineral soil solutions of these ecosystems of about 24 .

Generally, passage of rainwater through the forest canopy increased the DOC/DON ratio substantially, from 2.1-2.4 to 11-16 (Fig. 2). The forest floor leachate had DOC/DON values of 20, 24 and 20 in the SB, CP and CPN stand, respectively, which were only just lower than the $\mathrm{C} / \mathrm{N}$ ratios of the respective forest floor materials (22, 27 and 27, respectively).

During passage through the mineral soil, the DOC/DON ratio remained more or less constant $( \pm 20-24$ in $\mathrm{CP}$ and $\mathrm{CPN}$ ) or increased to a maximum of 31 (SB), and then decreased sharply to 7-12 in the groundwater, suggesting a strong preferential removal of DOC compared to DON. Generally, DON showed smaller changes within the forest ecosystem compared to DOC, pointing towards lower overall reactivity of $\mathrm{N}$-containing DOM compounds.

\subsection{Contribution of DON to TDN}

On average, about $30 \%$ of the TDN in precipitation water consisted of DON (Table 5). Increase in DIN during passage through the forest canopies at the three stands, in combination with the limited DON release (or retention in the SB and $\mathrm{CP}$ stands) from the canopies, substantially reduced the contribution of DON to TDN fluxes (Table 5). DON represented 22,17 and $19 \%$ of TDN in throughfall water in the SB, CP and CPN stands, respectively. The (relatively) larger DON release from forest floor material increased again the contribution of DON to TDN in the forest floor leachates in SB and CP. On the contrary, very large DIN release from the CPN forest floor lowered the DON contribution to TDN in forest floor percolates to only $15 \%$. The contribution of DON to TDN decreased with depth in the mineral soil in the SB and CPN stands, whereas it remained rather constant in the CP stand.

\section{Discussion}

\subsection{Major sources and sinks of DOC and DON}

Although atmospheric deposition was a minor source of DOC in these ecosystems, it was the major net source of DON. Neff et al. (2002) indicated that the major sources of atmospheric organic nitrogen (AON) include byproducts of reactions between $\mathrm{NO}_{\mathrm{x}}$ and hydrocarbons, marine and terrestrial sources of reduced (amino acid) $\mathrm{N}$ and the long-range transport of organic matter (dust, pollen etc.) and bacteria.

The highest DOC, DON and DIN concentrations and fluxes were found in the forest floor leachate. The lower $\mathrm{C} / \mathrm{N}$ ratio of the DOM released from the forest floor material compared to the solid phase $\mathrm{C} / \mathrm{N}$ is somewhat in contradiction to the general assumption that DON release follows that of DOC (the passive carbon vehicle). Several studies (e.g. McDowell et al., 1998; Michalzik and Matzner, 1999; Solinger et al., 2001) found higher $\mathrm{C} / \mathrm{N}$ ratios of DOM in forest floor leachate compared to the solid phase organic matter. Brookshire et al. (2007) presented two hypothetical mechanisms 

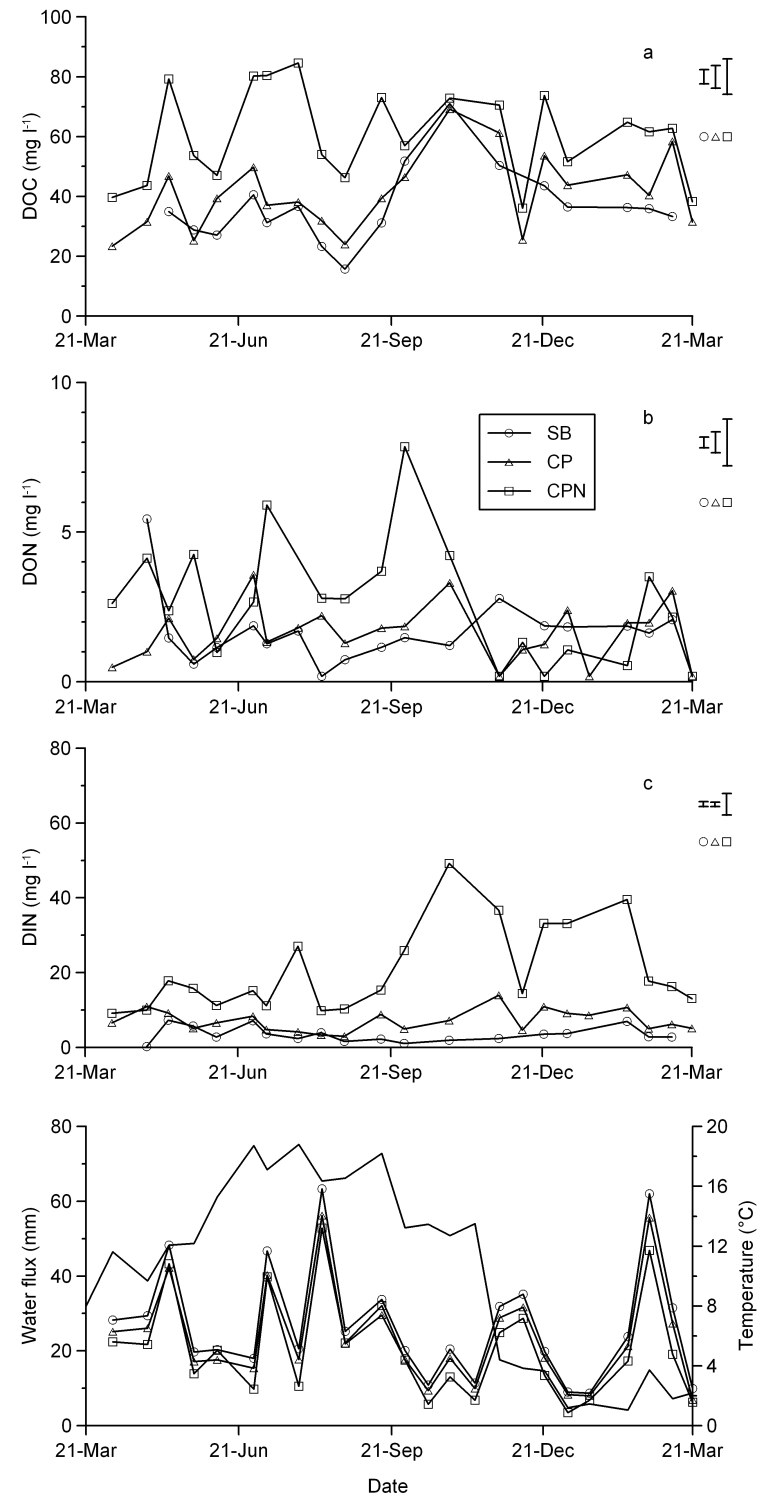

Fig. 2. Average concentrations of dissolved organic carbon (DOC) (a), nitrogen (DON) (b) and dissolved inorganic nitrogen (DIN) (c) in the zero-tension lysimeter samples from the forest floor collected from 21 March 2005 to 21 March 2006. Bars represent the average standard error over the monitoring period per forest stand. Water fluxes of litter leachate in the three forest stands and average air temperature during the measuring fortnights (d). (SB: silver birch, $\mathrm{CP}$ : Corsican pine, $\mathrm{CPN}$ : high deposition Corsican pine).

for a stoichiometric $\mathrm{N}$ enrichment of DOM as found here: (i) abiotic reaction between DOM and inorganic nitrogen and (ii) the microbial (mycorrhizal) incorporation of DIN with subsequent release of DON. Davidson et al. (2003) described an abiotic mechanism producing DON through reaction of nitrite with DOM. Colman et al. (2007), however, found that this apparent abiotic $\mathrm{N}$ incorporation was likely the result of iron interference with nitrate measurements.
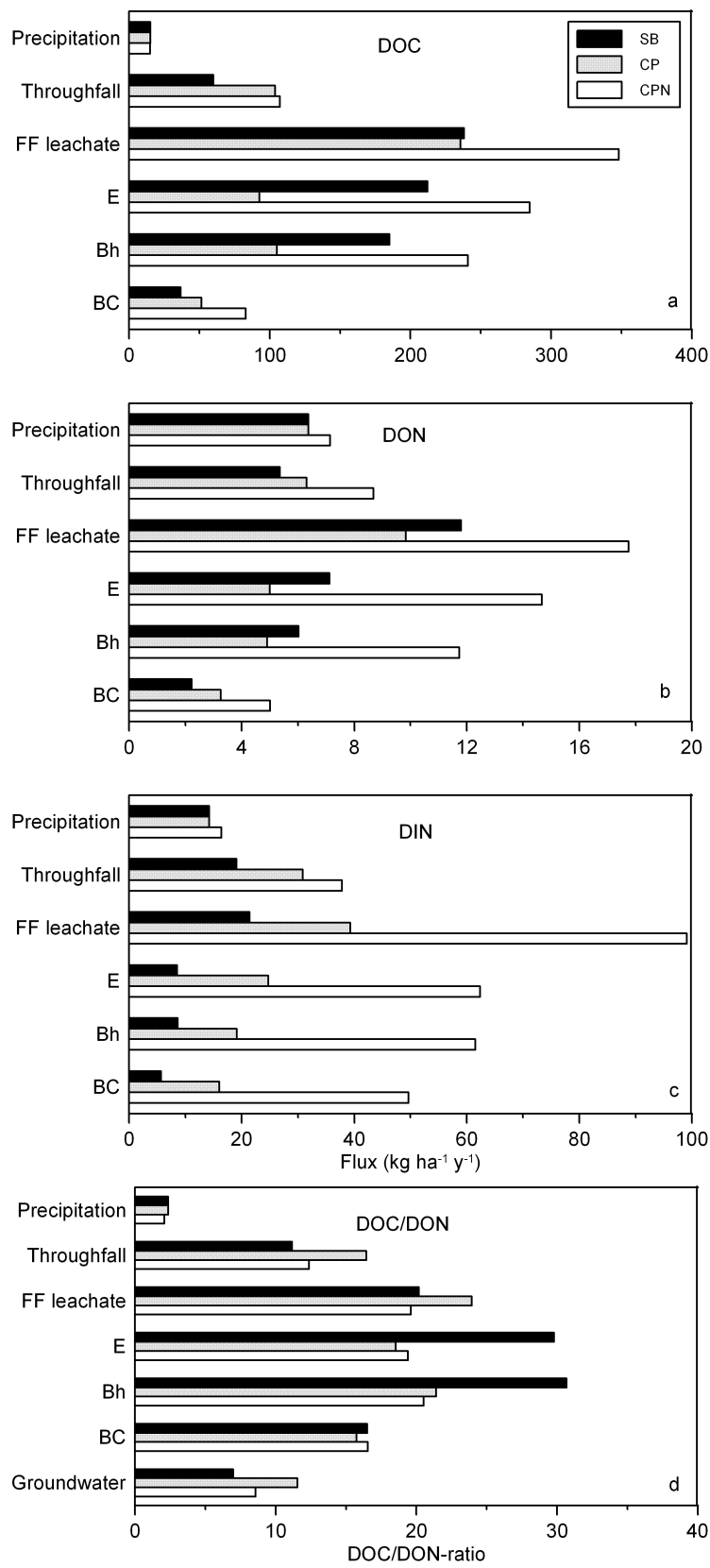

Fig. 3. Average concentrations of dissolved organic carbon (DOC) (a) and nitrogen (DON) (b) and dissolved inorganic nitrogen (DIN) (c) in the lysimeter samples from the BC horizon collected from 21 March 2005 to 21 March 2006. Bars represent the average standard error over the monitoring period per forest stand. Water fluxes (+=downward, $-=$ upward) under the three forest stands and average soil temperature during the measuring fortnights (d). (SB: silver birch, CP: Corsican pine, CPN: high deposition Corsican pine).

Our results show that the mineral soil appeared to be the major sink for DOC and DON. Most retention in SB and CPN was found in the deeper (Bs and BC) soil horizons rich in iron and/or aluminum oxyhydroxides, recognized as 
strong sorbents for DOM (Kaiser et al., 1996), pointing towards sorption as the main removal mechanism. In CP retention was stronger closer to the soil surface, but this was related to Bs material laying closer to the surface. Also Qualls and Haines (1992) indicated that adsorption, rather than biodegradation, is more likely responsible for maintaining low DOC concentrations in the mineral soil.

We found decreasing DOC/DON ratios with increasing soil depth in the three forest stands, which is in accordance to the findings of Michalzik et al. (2001) and Lajtha et al. (2005). The latter attributed this difference to the preferential sorption of high $\mathrm{C} / \mathrm{N}$ hydrophobic DOM to mineral soil constituents over hydrophilic DOM with a much lower and less variable $\mathrm{C} / \mathrm{N}$ ratio. Several studies found higher DOC/DON ratios in the hydrophilic and hydrophobic acid fractions (which were found to be preferentially sorbed to iron and aluminum oxyhydroxides) and lower ratios in the hydrophilic neutrals fraction (e.g. Qualls and Haines, 1991). Sequential batch sorption experiments with the soils from this study involving chemical fractionation of DOC and DON (Vandenbruwane, 2008) confirmed the lower reactivity of DON compared to DOC.

Substantial amounts of DOC (71-76\%) and DON (14$32 \%)$ were retained between the lower boundary of the mineral soil profile $(<65 \mathrm{~cm})$ and the groundwater. Schwesig et al. (2003) found that DOC leaching from the rooting zone is highly resistant to mineralization and concluded that the further decrease of DOC concentrations in the subsoil could not be attributed to mineralization. Siemens et al. (2003) showed that substantial amounts of DOM were removed by sorption in deeper mineral subsoil, and Jardine et al. (2006) indicated the importance of DOC accumulation in lower horizons for carbon sequestration.

\subsection{Influence of the forest type}

Although the adjacent SB and CP stands are subject to identical bulk precipitation deposition, the DIN (and other ions) throughfall water fluxes tended to differ between both stands (but not significantly). It is generally known that, under identical site and meteorological conditions, coniferous forests receive more atmospheric deposition via throughfall water than deciduous forest types. This difference can be explained by (i) the summer-green character of the deciduous forest (Rothe et al., 2002), (ii) differences in vegetation structure such as leaf area index (LAI), canopy height and canopy closure (Erisman and Draaijers, 2003) and (iii) differences in form or shape of leaves or needles (Smith, 1981). As a result, observed differences in DOM dynamics between forest types are not solely due to inherent differences in DOM quality and quantity, but may result from indirect differences in biogeochemical and hydrological cycles which are related to the forest type. The coniferous forest had higher DOC and DON throughfall water fluxes compared to the decidu- ous forest which can result from different canopy interactions between the studied forest types.

In contrast to the observed throughfall water fluxes, the forest type only slightly affected the DOC and DON fluxes via forest floor leachate. A higher percentage of the DON input with forest floor leachate was retained in the mineral soil of the SB stand (81\%) compared to the CP stand (67\%), suggesting a difference in the distribution of $\mathrm{N}$ over the different DOM fractions. Since the CP stand intercepted more DIN than the SB stand, this finding is in accordance with the findings of McDowell et al. (2004) that proportionally more DON is in the hydrophilic fractions as a result of chronic nitrogen amendments. Although the DOC/DON ratio in most strata differed substantially between both stands, the DOM leaching from the BC horizon showed a similar DOC/DON ratio under both forest types. However, since the number of measurements was both spatially and temporally limited, the observed differences should be interpreted with caution.

The major differences between the two forest stands were in the relative contribution of DON to TDN fluxes in the different strata. Whereas DON was a substantial part of total nitrogen fluxes in the deciduous forest (28-46\%), its contribution to TDN was only $20 \%$ at most in the coniferous forest. Since absolute DON fluxes differed only slightly between both forest types, the differences in the DON/TDN ratio were mainly due to large differences in DIN fluxes.

\subsection{Influence of forest edge proximity}

One of the objectives of this study was to investigate the effect of different levels of $\mathrm{N}$ throughfall deposition on the dynamics of DOC and DON. Therefore, a forest stand CPN was selected with the forest edge oriented to the prevailing wind direction. Forest edges are more effective at filtering atmospheric deposition than forest interiors; they are subject to a so-called edge effect on throughfall deposition (De Schrijver et al., 2007; Draaijers, 1993). This edge effect significantly increases throughfall $\mathrm{N}$ deposition compared to the forest interior and decreases exponentially with increasing distance from the forest edge. The CPN stand indeed received higher TDN inputs with throughfall water compared to the $\mathrm{CP}$ and SB stands $(+25 \%)$.

Overall, larger fluxes of DOC, DON and DIN were observed in the CPN stand compared to the CP and SB stands. These differences are mainly introduced during passage of the water through the forest floor material, which points towards a major impact of $\mathrm{N}$ deposition and forest edge proximity on DOM release from the forest floor. Although there was less forest floor material in the CPN stand, more DOM was released compared to the CP stand, suggesting a faster turnover of organic material. Various hypothetical mechanisms have been formulated and tested which may be responsible for the enhanced DOM leaching as a result of increased nitrogen deposition (e.g. Carreiro et al., 2000; Blackwood et al., 2007), but results were often not consistent. It is 
questionable whether the relatively limited increase in measured $\mathrm{N}$ input (25\%) can result in the large increase in DOM release from the forest floor (82\%). However, two other factors could help to explain the elevated DOM release:

i) the $\mathrm{N}$ throughfall deposition measured between March 2005 and March 2006 is relatively low compared to earlier studies in the same region under similar conditions (Neirynck et al., 2002). Although the $\mathrm{N}$ deposition more than doubled between 1870 and 1980 (Asman et al., 1988), recent data indicated that $\mathrm{N}$ deposition in Flanders decreased with $18 \%$ between 1990 and 2004 (MIRA, 2006). Thus, although the $\mathrm{N}$ deposition and the difference in $\mathrm{N}$ input between both stands is relatively small to date, the biogeochemical cycles in all observed stands, but especially in the CPN stand (because of its proximity to the forest edge), are probably still influenced by the very large historical nitrogen inputs which lasted for several decades. Due to its colloidal properties, the physico-chemical release of DOM from the forest floor is influenced to a considerable extent by the ionic strength and ionic composition of throughfall water (Kalbitz et al., 2000).

ii) Besides the elevated ion throughfall deposition flux, the proximity of a forest edge furthermore influences the microclimatic conditions (like light intensity, air temperature, relative humidity, soil moisture and litter moisture) (Marchand and Houle, 2006) which in turn also might affect DOM dynamics. Therefore, observed differences in DOM dynamics between both coniferous stands (CP and CPN) were probably due to a combination of factors influenced by an edge effect of which increased $\mathrm{N}$ input is one.

The combination of larger DOC fluxes entering the mineral soil with forest floor leachate, together with an almost equal percentagewise retention (by sorption) in the mineral soil (78\% in CP and 76\% in CPN) results in larger DOC retaining in the mineral soil in CPN $\left(84 \mathrm{~kg} \mathrm{ha}^{-1} \mathrm{yr}^{-1}\right.$ additional DOC retained compared to $\mathrm{CP}$ ). This is in agreement with the findings of Hyvönen et al. (2008) concerning the impact of long-term $\mathrm{N}$ addition on carbon stocks in soils in northern Europe. Also, the DOC and DON fluxes leaving the rooting zone were substantially larger as a result of the forest edge effect. Similarly, Pregitzer et al. (2004) reported DOC and DON exports to be elevated by more than 3 and 6 times respectively after 8 years of artificial nitrate additions as $\mathrm{NaNO}_{3}\left(30 \mathrm{~kg} \mathrm{Nha}^{-1} \mathrm{yr}^{-1}\right)$.

We assessed whether differences in DOC sorption capacity between stands could have influenced results of DOC (and DON) leaching between forest type and deposition level. To this end, we recalculated $\mathrm{Fe}_{\mathrm{Ox}}$ and $\mathrm{Al}_{\mathrm{ox}}$ concentrations in the $\mathrm{B}$ and $\mathrm{B} / \mathrm{C}$ horizons on a molar basis, weighing molar concentrations with depth of the $\mathrm{B}+\mathrm{B} / \mathrm{C}$ horizons (assuming an overall bulk density of 1.5 ). SB tended to have a larger ad- sorptive capacity ( $58.6 \mathrm{~mol} \mathrm{Fe} e_{\text {ox }}+\mathrm{Al}_{\mathrm{ox}} \mathrm{m}^{-2}$ ) compared to $\mathrm{CP}$ and $\mathrm{CPN}$ (36.3 and $37.3 \mathrm{~mol} \mathrm{Fe} \mathrm{ox}_{\mathrm{ox}}+\mathrm{Al}_{\mathrm{ox}} \mathrm{m}^{-2}$, respectively). However, DOC retention in the mineral soil (which can be considered mainly as sorption) in these forest was found to be 201, 185 and $265 \mathrm{~kg} \mathrm{DOC} \mathrm{ha}^{-1} \mathrm{yr}^{-1}$ in SB, CP and CPN, respectively (Vandenbruwane, 2008), which does not relate directly to $\mathrm{Fe}_{\mathrm{ox}}$ and $\mathrm{Al}_{\mathrm{Ox}}$ concentrations. Vandenbruwane et al. (2007b) indeed found that while the DOC sorption capacity in the Bh horizon was $80-100 \%$ saturated, it was only from $39-45 \%$ and $16-18 \%$ saturated in the Bs and BC horizons, respectively. Therefore, possible differences in sorption capacity do not seem to have influenced DOC leaching in the different forest stands.

Still, the overall higher DIN fluxes in the CPN stand resulted in a smaller relative contribution of DON to TDN. Park and Matzner (2006) also found that the contribution of nitrate increased whereas that of DON decreased with increasing throughfall nitrogen input. Our results furthermore suggest that there is a difference in the location within the ecosystem strata where maximum nitrification occurs. In CP, most nitrification seems to occur in the forest floor, while in CPN this seems to be in the upper mineral horizons ( $\mathrm{A}$ and $\mathrm{E}$ ).

\subsection{Leaching of DON}

Previous studies of DON leaching under forest often considered only DON concentrations directly beneath the forest floor (e.g. McDowell et al., 1998). Other studies where DON in the mineral soil was measured were often based on measurements of concentrations rather then fluxes. In the few studies where fluxes were calculated, this was mostly done based on much simplified water balances (e.g. Pregitzer et al., 2004). In this study time series of DON measurements in different ecosystem strata were coupled to accurate hydrological flux calculations to yield a reliable estimate of DON leaching fluxes below rooting depth and its contribution to overall $\mathrm{N}$ leaching losses.

Several studies pointed out that nitrogen leaching in oligotrophic forests mainly occurs in the organic form (Currie et al., 1996; Perakis and Hedin, 2002; Qualls et al., 2002). Our study confirms the limited contribution of DON to total nitrogen leaching (9-28\%) in forests subject to high $\mathrm{N}$ loads. Contrary to the order of absolute DON leaching fluxes $(\mathrm{CPN}>\mathrm{CP}>\mathrm{SB})$, the contribution of DON to total nitrogen leaching followed the order $\mathrm{SB}>\mathrm{CP}>\mathrm{CPN}$. This basically means that DON leaching is relatively independent of vegetation type and $\mathrm{N}$ inputs, and that DON/TDN ratios are regulated mainly by changes in DIN fluxes, which in turn are controlled by the overall throughfall $\mathrm{N}$ input and by the ecosystem $\mathrm{N}$ status. This is in accordance with the findings of Park and Matzner (2006) that the contribution of nitrate increased whereas that of DON decreased with increasing throughfall nitrogen input. The contribution of DON to the total dissolved nitrogen concentration in groundwater was 
only $6-14 \%$, probably as a result of additional DON retention in the deeper mineral horizons.

Our data indicated that the total nitrogen input (DON+DIN) with throughfall water was higher than the total $\mathrm{N}$ output through leaching to the groundwater in the three replicated plots of the SB and CP stand. This means that $\mathrm{N}$ still accumulates in these forest ecosystems. The opposite was found in the CPN plots, namely the export of nitrogen was larger than the input with throughfall water. These findings show that this ecosystem released nitrogen instead of taking it up, which may be an indication for nitrogen (over)-saturation as a result of the long-term high nitrogen deposition. The very large TDN concentrations at $65 \mathrm{~cm}$ depth especially in CPN (around $20 \mathrm{ppm}$ TDN) and in the groundwater (flux weighed average concentration of $24.0 \mathrm{ppm}$ DIN), both mainly as $\mathrm{NO}_{3}^{-}$, are of serious concern. These groundwater concentrations are confirmed by balance calculations of yearly water $\left(224 \mathrm{~mm} \mathrm{yr}^{-1}\right.$, Table 4$)$ and DIN fluxes below $65 \mathrm{~cm}\left(56.8 \mathrm{~kg} \mathrm{DIN} \mathrm{ha}^{-1} \mathrm{yr}^{-1}\right)$, yielding a concentration of $25.4 \mathrm{ppm}$. It seems that especially in these pine forests excessive atmospheric inputs have created a situation where groundwater nitrate tresholds can no longer be met, especially in the forest edges exposed to the prevailing wind directions.

\section{Conclusions}

The inclusion of a forest edge allowed to evaluate long term differences in $\mathrm{N}$ deposition without the need for multi year artificial addition of $\mathrm{N}$. Therefore, the results of this study reflect the true influence of long term elevated $\mathrm{N}$ deposition and gradients therein. Also, the monitoring of fluxes of DOC, DON and DIN at a large number of ecosystem strata (precipitation, throughfall, forest floor, three mineral soil horizons and groundwater) allowed for a detailed analysis of sinks and sources of these compounds. Our results show that for monitoring of DOC and DON dynamics and leaching to groundwater sufficient vertical resolution is necessary, and measurements in only one or two ecosystem strata will not allow to make correct conclusions.

DON represented $30 \%$ of the TDN input with precipitation. The contribution of DON to ecosystem $\mathrm{N}$ inputs is apparently not negligible although it has frequently been omitted from ecosystem nutrient balances. The contribution of DON to TDN leaching was mainly determined by the DIN fluxes. Since these DIN fluxes are in turn determined by canopy interception of $\mathrm{N}$, the DON/TDN ratio is influenced by forest type and forest edge proximity.

\section{Appendix A}

\section{Calculation of hydrological fluxes}

The fortnightly water fluxes of precipitation and canopy throughfall $(\mathrm{mm})$ were determined using the measured water volumes at each sampling occasion. Because of the high temporal and spatial variability of the water volumes collected with the zero-tension lysimeters, forest floor leachate fluxes could not be quantified using the measured volumes.

Water balances and fluxes were calculated for the three different forest stands and for each fortnightly sampling period of the one year monitoring program using the SWAP model (Van Dam, 2000; Van Dam et al., 1997). The water balance within this model can be described as:

$P=E+R+D+Q+\Delta S$

where $P$ is the precipitation, $E$ the evapotranspiration, $Q$ the leaching flux, $R$ the runoff, $D$ the lateral drainage and $\Delta S$ the change in the water storage in the soil profile.

Within the SWAP model, the potential evapotranspiration is calculated using the Penman-Monteith equation. The potential evapotranspiration is divided over interception evaporation, potential soil evaporation and potential transpiration. The total amount of interception in the forest stands was calculated according to Gash et al. (1995). Potential transpiration is calculated from the potential evapotranspiration by reducing the evapotranspiration during rainfall with the calculated interception evaporation.

To calculate the hydrological fluxes, the application of the SWAP model requires (i) meteorological data, (ii) abiotic characteristics of the site (soil physical and drainage characteristics, grondwater level) and (iii) vegetation dependent parameters (including crop resistance, LAI or soil cover, storage capacity of the crown, tree height, rooting depth and root distribution).

\section{A1 Meteorological data}

The model requires daily meteorological data of precipitation, net radiation, temperature, wind speed and relative humidity. These data were not collected on the site, but were obtained from the nearest meteorological station of the Royal Meteorological Institute of Belgium, i.e. at Retie. Precipitation may vary considerably over short distances, possibly leading to large differences between data from the meteorological station and the actual precipitation at the site. To obtain the best estimate of the daily precipitation at the site, daily precipitation data from the meteorological station were multiplied with the ratio of the fortnightly precipitation at the site, measured in the open field, to the fortnightly precipitation at the meteorological station. 
Table A1. Measured soil hydrological characteristics $\left(\theta_{\text {res }}=\right.$ residual water content; $\theta_{\text {sat }}=$ saturated water content; $\alpha=$ shape parameter; $n=$ shape parameters; $K_{\mathrm{sat}}=$ saturated hydraulic conductivity) for the three sites under investigation .

\begin{tabular}{lrrrrr}
\hline $\begin{array}{l}\text { Depth }(\mathrm{cm}) \\
(\mathrm{cm})\end{array}$ & $\begin{array}{r}\theta_{\text {res }}^{\mathrm{a}} \\
\left(\mathrm{cm}^{3} \mathrm{~cm}^{-3}\right)\end{array}$ & $\begin{array}{r}\theta_{\text {sat }}^{\mathrm{a}} \\
\left(\mathrm{cm}^{3} \mathrm{~cm}^{-3}\right)\end{array}$ & $\begin{array}{r}\alpha^{\mathrm{a}} \\
\mathrm{cm}^{-1}\end{array}$ & $\begin{array}{r}n^{\mathrm{a}} \\
(-)\end{array}$ & $\begin{array}{r}K_{\text {sat }}^{\mathrm{b}} \\
\left(\mathrm{cm} \mathrm{d}^{-1}\right)\end{array}$ \\
\hline $\mathrm{SB}$ & & & & & \\
$5-0^{\mathrm{c}}$ & 0.000 & 0.500 & 0.100 & 1.25 & 800 \\
$0-17$ & 0.068 & 0.405 & 0.021 & 1.82 & 336 \\
$17-21$ & 0.076 & 0.409 & 0.020 & 2.83 & 404 \\
$21-58$ & 0.034 & 0.332 & 0.017 & 3.92 & 321 \\
$>58$ & 0.031 & 0.315 & 0.016 & 3.16 & 334 \\
CP & & & & & \\
$3-0^{\mathrm{c}}$ & 0.000 & 0.500 & 0.100 & 1.25 & 800 \\
$0-30$ & 0.074 & 0.432 & 0.024 & 2.21 & 533 \\
$30-37$ & 0.063 & 0.450 & 0.020 & 2.25 & 534 \\
$37-61$ & 0.044 & 0.357 & 0.018 & 3.56 & 440 \\
$>61$ & 0.034 & 0.316 & 0.016 & 3.31 & 348 \\
CPN & & & & & \\
$2-0^{\mathrm{c}}$ & 0.000 & 0.500 & 0.100 & 1.25 & 800 \\
$0-29$ & 0.078 & 0.405 & 0.029 & 1.89 & 217 \\
$29-42$ & 0.066 & 0.383 & 0.027 & 1.87 & 251 \\
$42-73$ & 0.025 & 0.303 & 0.023 & 3.57 & 658 \\
$>73$ & 0.039 & 0.300 & 0.019 & 2.86 & 386 \\
\hline
\end{tabular}

\footnotetext{
${ }^{a}$ Parameters resulting from the fit of the van Genuchten equation to the datapoints of the measured water retention curves;

${ }^{b}$ parameter resulting from laboratory measurements;

${ }^{c}$ data for the forest floor are based on Tiktak and Bouten (1994).
}

\section{A2 Soil physical properties}

Water retention curves of the forest soils at different depths were determined in the lab by measuring the water content of intact soil cores gravimetrically at six different matrix potentials $(-3,-5,-7,-10,-33$ and $-100 \mathrm{kPa})$. This was done by means of the sandbox apparatus (Eijkelkamp Agrisearch Equipment, Giesbeek, The Netherlands) for matrix potentials between -3 and $-10 \mathrm{kPa}$, and with pressure chambers (Soilmoisture Equipment, Santa Barbara, CA) for matrix potentials of -33 and $-100 \mathrm{kPa}$. The model of van Genuchten (1980) was fitted to these data points to obtain the water retention parameters (Table A1). The saturated hydraulic conductivity $\left(K_{\text {sat }}\right)$ was measured in the lab on intact soil cores using a constant head permeameter (Eijkelkamp Agrisearch Equipment, Giesbeek, The Netherlands).

Since the groundwater level was at a depth of $1.5 \mathrm{~m}$ or more throughout the experiment, free drainage of the soil profile at a depth of $90 \mathrm{~cm}$ was assumed. Run-off or runon was set to zero since the study sites were located on flat terain with sandy soils. No lateral drainage was calculated for the three sites since ditches and canals were absent in the immediate proximity of the study plots.

\section{A3 Stand characteristics}

The most important stand parameters within the model are tree height, soil cover fraction $(S C)$, storage capacity of the canopy $(S)$, minimum crop resistance $\left(r_{\text {crop }}\right)$, rooting depth $\left(D_{\text {root }}\right)$ and root distribution $\left(\ell_{\text {root }}\right)$. Tree height was measured using an ultrasonic height meter (Vertex III, Haglöf Sweden $\mathrm{AB}$ ), while the other stand parameters were estimated using the parameter estimation package PEST (see further).

\section{A4 Parameter estimation}

A number of parameters of the SWAP model were estimated using the model-independent parameter estimation package PEST (Watermark Numerical Computing, USEPA). In a first parameter estimation run, the crop-related parameters soil cover fraction $(S C)$, free throughfall coefficient $(p)$ and the storage capacity of the canopy $(S$ ) for three development stages (DVS) were estimated for each of the three forest stands (Table A2). Therefore, the fortnightly throughfall volumes generated by SWAP were calibrated to the fortnightly volumes measured on site (Fig. A1). A second parameter estimation run was performed in order to calibrate the SWAP model for the course of matrix potentials and moisture contents, which were measured in the mineral soil at three and four different depths, respectively. The parameters estimated 
Table A2. The most important stand and crop characteristics used in the SWAP model calculations.

\begin{tabular}{lcccccc}
\hline Stand & $\begin{array}{c}D_{\text {root }}^{\mathrm{a}, \mathrm{f}} \\
(\mathrm{cm})\end{array}$ & $\begin{array}{c}r_{\text {canopy }}^{\mathrm{b}, \mathrm{f}} \\
(\mathrm{s} / \mathrm{m})\end{array}$ & $\begin{array}{c}\ell_{\text {root }}^{\mathrm{c}, \mathrm{f}} \\
(-)\end{array}$ & $\begin{array}{c}S C^{\mathrm{d}, \mathrm{f}} \\
\left(\mathrm{m}^{2} \mathrm{~m}^{-2}\right)\end{array}$ & \multicolumn{2}{c}{$\begin{array}{c}\text { Interception parameters } \\
p^{\mathrm{e}, \mathrm{f}}(-)\end{array}$} \\
\hline SB & 87 & 149 & $0.00 / 8.69 / 0.00 / 0.77$ & $0.93 / 0.92 / 0.90^{\mathrm{g}}$ & $0.70 / 0.98 / 0.70^{\mathrm{g}}$ & $0.40 / 0.45 / 0.57^{\mathrm{g}}$ \\
$\mathrm{CP}$ & 71 & 138 & $0.09 / 3.34 / 0.00 / 1.70$ & $1.00 / 1.00 / 0.93$ & $0.69 / 0.69 / 0.62$ & $0.47 / 0.39 / 0.23$ \\
$\mathrm{CPN}$ & 71 & 138 & $0.09 / 3.34 / 0.00 / 1.70$ & $0.91 / 1.00 / 0.77$ & $0.63 / 0.58 / 0.40$ & $0.37 / 0.35 / 0.29$ \\
\hline
\end{tabular}

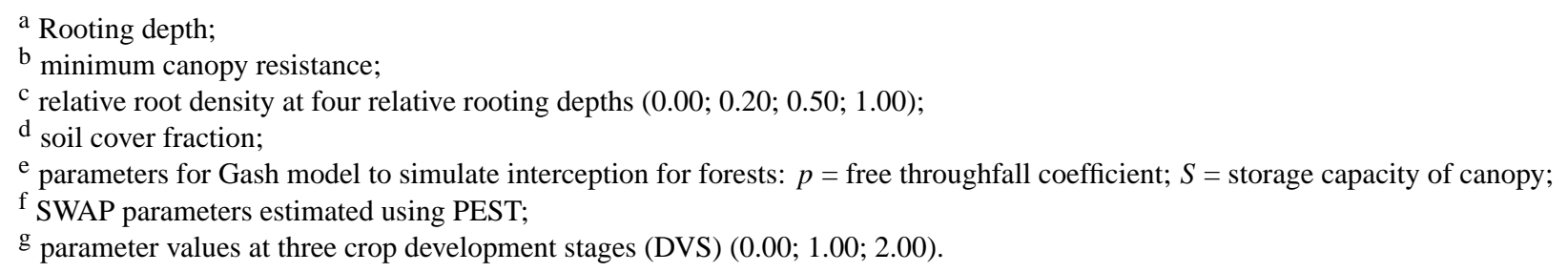

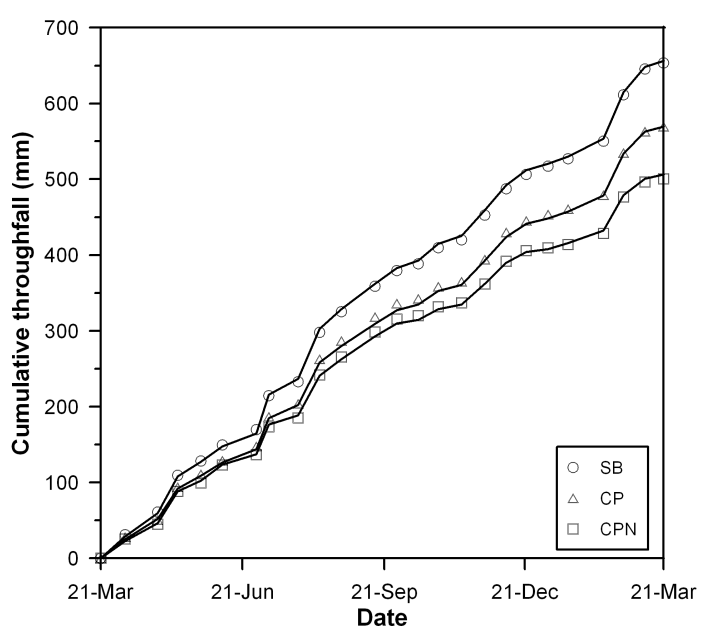

Fig. A1. Cumulative throughfall volume ( $\mathrm{mm})$ for the three forest stands in Ravels as measured on site from 21 March 2005 till 21 March 2006. The data points represent field measurements, whereas the solid lines represent the SWAP simulations optimized by PEST during calibration.

in this run were: the exponent in the hydraulic conductivity function (van Genuchten-Mualem equation) $(\lambda)$ for the litter layer and the mineral soil, rooting depth, minimum canopy resistance and relative root density as a function of relative rooting depth (Tables A1 and A2).

Acknowledgements. This study was funded by the Special Research Fund (BOF) of Ghent University. Steven Sleutel and An De Schrijver are post-doctoral research fellows of the Science Foundation Flanders (FWO). We thank T. Coddens, S. Schepens, L. Willems and G. De bruyn for the chemical analyses and G. Geudens, K. Avaux, L. Deboosere and M. Schatteman for help with the experimental set-ups. We thank the three anonymous reviewers for their valuable comments.

Edited by: S. Bouillon

\section{References}

Aber, J. D., Nadelhoffer, K. J., Steudler, P., and Melillo J. M.: Nitrogen saturation in Northern forest ecosystems, BioScience, 39, 378-386, 1989.

Alcock, M. R. and Morton, A. J.: Nutrient content of throughfall and stemflow in woodland recently established on heathland, J. Ecol., 73, 625-632, 1985.

Asman, W. A. H., Drukker, B, and Janssen, A. J.: Modelled historical concentrations and depositions of ammonia and ammonium in Europe, Atmos. Environ., 22, 725-735, 1988.

Blackwood, C. B., Waldrop, M. P., Zak, D. R., and Sinsabaugh, R. L.: Molecular analysis of fungal communities and laccase genes in decomposing litter reveals differences among forest types but no impact of nitrogen deposition, Environ. Microbiol., 9, 13061316, 2007.

Brookshire, E. N. J., Valett, H. M., Thomas, S. A., and Webster, J. R.: Atmospheric N deposition increases organic $\mathrm{N}$ loss from temperate forests, Ecosystems, 10, 252-262, 2007.

Carreiro, M. M., Sinsabaugh, R. L., Repert, D. A., and Parkhurst, D. F.: Microbial enzyme shifts explain litter decay responses to simulated nitrogen deposition, Ecology, 81, 2359-2365, 2000.

Christ, M. J. and David, M. B.: Temperature and moisture effects on the production of dissolved organic carbon in a spodosol, Soil Biol. Biochem., 28, 1191-1199, 1996.

Colman, B. P., Fierer, N., and Schimel, J. P.: Abiotic nitrate incorporation in soil: is it real?, Biogeochemistry, 84, 161-169, 2007.

Currie, W. S., Aber, J. D., and McDowell, W. H.: Vertical transport of dissolved organic $\mathrm{C}$ and $\mathrm{N}$ under long term $\mathrm{N}$ amendments in pine and hardwood forests, Biogeochemistry, 35, 471-505, 1996.

Davidson, E. A., Chorover, J., and Dail, D. B.: A mechanism of abiotic immobilization of nitrate in forest ecosystems: the ferrous wheel hypothesis, Glob. Change Biol., 9, 228-236, 2003.

De Schrijver, A., Geudens, G., Augusto, L., Staelens, J., Mertens, J., Wuyts, K., Gielis, L., and Verheyen, K.: The effect of forest type on throughfall deposition and seepage flux: a review, Oecologia, 153, 663-674, 2007.

Draaijers, G. P. J.: The variability of atmospheric deposition to forests: the effects of canopy structure and forest edges, $\mathrm{PhD}$ Dissertation, Utrecht University, 1993.

Erisman, J. W. and Draaijers, G.: Deposition to forests in Europe: 
most important factors influencing dry deposition and models used for generalisation, Environ. Poll., 124, 379-388, 2003.

Evans, A., Zelazny, L. W., and Zipper, C. E.: Solution parameters influencing dissolved organic carbon in 3 forest soils, Soil Sci. Soc. Am. J., 52, 1789-1792, 1988.

Fang, Y. T., Zhu, W. X., Gundersen, P., Mo, J. M., Zhou, G. Y., and Yoh, M.: Large loss of dissolved organic nitrogen from nitrogensaturated forests in subtropical China, Ecosystems, 12, 33-45, 2009

Fang, Y. T., Gundersen, P., Mo, J. M., and Zhu, W. X.: Input and output of dissolved organic and inorganic nitrogen in subtropical forests of South China under high air pollution, Biogeosciences, 5, 339-352, 2008, http://www.biogeosciences.net/5/339/2008/.

Galloway, J. N., Schlesinger, W. H., Levy, H., Michaels A., and Schnoor J. L.: Nitrogen fixation: anthropogenic enhancement environmental response, Global Biogeochem. Cy., 9, 235-252, 1995.

Gash, J. H. C., Lloyd, C. R., and Lachaud, G.: Estimating sparse forest rainfall interception with an analytical model, J. Hydrol., 170, 79-86, 1995.

Hyvönen, R., Persson, T., Andersson, S., Olsson, B., Agren, G. I., and Linder, S.: Impact of long-term nitrogen addition on carbon stocks in trees and soils in northern Europe, Biogeochemistry, 89, 121-137, 2008.

Jackson, M. L., Lim, C. H., and Zelazny, L. W.: Oxides, hydroxides, and aluminosilicates, in: Methods of Soil Analysis, Part I: Physical and mineralogical methods, edited by: Klute, A., 2nd ed., ASA \& SSSA, Madison WI, USA, 101-150, 1986.

Jansen, J. J., Sevenster, J., and Faber, P. J.: Opbrengsttabellen voor belangrijke boomsoorten in Nederland, IBN rapport, no. 221, 240 pp., 1996 (in Dutch).

Jardine, P. M., Mayes, M. A., Mulholland, P. J., Hanson, P. J., Tarver, J. R., Luxmoore, R. J., McCarthy, J. F., and Wilson, G. V.: Vadose zone flow and transport of dissolved organic carbon at multiple scales in humid regions, Vadose Zone J., 5, 140-152, 2006.

Kaiser, K., Guggenberger, G., and Zech, W.: Sorption of DOM and DOM fractions to forest soils, Geoderma, 74, 281-303, 1996.

Kaiser, K., Guggenberger, G., and Zech, W.: Organically bound nutrients in dissolved organic matter fractions in seepage and pore water of weakly developed forest soils, Acta Hydroc. Hydrob., 28, 411-419, 2001.

Kalbitz, K., Solinger, S., Park, J.-H., Michalzik, B., and Matzner, E.: Controls on the dynamics of dissolved organic matter in soils: a review, Soil Sci., 165, 277-304, 2000.

Koroleff, F.: Simultaneous oxidation of nitrogen and phosphorus compounds by persulfate, in: Methods of seawater analysis, edited by: Grasshoff, K., Eberhardt, M., and Kremling, K., 2nd edn. Verlag Chemie, Weinheim, 1983.

Lajtha, K., Crow, S. E., Yano, Y., Kaushal, S. S., Sulzman, E., Sollins, P., and Spears, J. D. H.: Detrital controls on soil solution $\mathrm{N}$ and dissolved organic matter in soils: a field experiment, Biogeochemistry, 76, 261-281, 2005.

Magill, A. H., Aber, J. D., Berntson, G. M., McDowell, W. H., Nadelhoffer, K. J., Melillo, J. M., and Steudler, P.: Long-term nitrogen additions and nitrogen saturation in two temperate forests, Ecosystems, 3, 238-253, 2000.

Marchand, P. and Houle, G.: Spatial patterns of plant species richness along a forest edge: What are their determinants?, Forest
Ecol. Manag., 223, 113-124, 2006.

McDowell, W. H., Currie, W. S., Aber, J. D., and Yano, Y.: Effects of chronic nitrogen amendments on production of dissolved organic carbon and nitrogen in forest soils, Water Air Soil Pollut., 105, 175-182, 1998.

McDowell, W. H., Magill, A. H., Aitkenhead-Peterson, J. A., Aber, J. D., Merriam, J. L., and Kaushal, S. S.: Effects of chronic nitrogen amendment on dissolved organic matter and inorganic nitrogen in soil solution, Forest Ecol. Manag., 196, 29-41, 2004.

Michalzik, B. and Matzner, E.: Dynamics of dissolved organic nitrogen and carbon in a Central European Norway spruce ecosystem, Eur. J. Soil. Sci., 50, 579-590, 1999.

Michalzik, B., Kalbitz, K., Park, J.-H., Solinger, S., and Matzner, E.: Fluxes and concentrations of dissolved organic carbon and nitrogen - a synthesis for temperate forests, Biogeochemistry, 52, 173-205, 2001.

MIRA: Milieu- en natuurrapport Vlaanderen, Achtergronddocument 2006 Vermesting, edited by: Overloop, S., Bossuyt, M., Ducheyne, S., et al., Vlaamse Milieumaatschappij, online available at: www.milieurapport.be, 2006.

Neff, J. C., Holland, E. A., Dentener, F. J., McDowell, W. H., and Russell, K. M.: The origin, composition and rates of organic nitrogen deposition: A missing piece of the nitrogen cycle?, Biogeochemistry, 57/58, 99-136, 2002.

Neirynck, J., Van Ranst, E., Roskams, P., and Lust, N.: Impact of decreasing throughfall depositions on soil solution chemistry at coniferous monitoring sites in northern Belgium, Forest Ecol. Manag., 160, 127-142, 2002.

Park, J. H., Kalbitz, K., and Matzner, E.: Resource control on the production of dissolved organic carbon and nitrogen in a deciduous forest floor, Soil Biol. Biochem., 34, 813-822, 2002.

Park, J. H. and Matzner, E.: Detrital control on the release of dissolved organic nitrogen (DON) and dissolved inorganic nitrogen (DIN) form the forest floor under chronic $\mathrm{N}$ deposition, Environ. Pollut., 143, 178-185, 2006.

Perakis, S. S. and Hedin, L. O.: Nitrogen loss from unpolluted South American forests mainly via dissolved organic compounds, Nature, 415, 416-419, 2002.

Prechtel, A., Alewell, C., Michalzik, B., and Matzner, E.: Different effect of drying on the fluxes of dissolved organic carbon and nitrogen from a Norway spruce forest floor, J. Plant Nutr. Soil Sci., 163, 517-521, 2000.

Pregitzer, K. S., Zak, D. R., Burton, A. J., Ashby, J. A., and MacDonald, N. W.: Chronic nitrate additions dramatically increase the export of carbon and nitrogen from northern hardwood ecosystems, Biogeochemistry, 68, 179-197, 2004.

Qualls, R. G. and Haines, B. L.: Geochemistry of dissolved organic nutrients in water percolationg through a forest ecosystem, Soil Sci. Soc. Am. J., 55, 1112-1123, 1991.

Qualls, R. G. and Haines, B. L.: Biodegradability of dissolved organic matter in forest throughfall, soil solution and stream water, Soil Sci. Soc. Am. J., 56, 578-586, 1992.

Qualls, R. G., Haines, B. L., Swank, W. T., and Tyler, S. W.: Retention of soluble organic nutrients by a forested ecosystem, Biogeochemistry, 61, 135-171, 2002.

Raastad, I. A. and Mulder, J.: Dissolved organic matter (DOM) in acid forest soils at Gårdsjon (Sweden): natural variabilities and effects of increased input of nitrogen and of reversal of acidification, Water Air Soil Pollut., 114, 199-219, 1999. 
Rothe, A., Huber, C., Kreutzer, K., and Weis, W.: Deposition and soil leaching in stands of Norway spruce and European Beech: Results from the Höglwald research in comparison with other European case studies, Plant Soil, 240, 33-45, 2002.

Schwesig, D., Kalbitz, K., and Matzner, E.: Mineralization of dissolved organic carbon in mineral soil solution of two forest soils, J. Plant Nutr. Soil Sci., 166, 585-593, 2003.

Siemens, J., Haas, M., and Kaupenjohann, M.: Dissolved organic matter induced denitrification in subsoils and aquifers?, Geoderma, 113, 253-271, 2003.

Sjöberg, G., Bergkvist, B., Berggren, D., and Nilsson, S. I.: Longterm $\mathrm{N}$ addition effects on the $\mathrm{C}$ mineralization and DOC production in mor humus under spruce, Soil Biol. Biochem., 35, 1305-1315, 2003.

Smith, W.: Air pollution and forests: interactions between air contaminants and forest ecosystems, New York, Springer Verlag, 397 pp., 1981.

Solinger, S., Kalbitz, K., and Matzner, E.: Controls on the dynamics of dissolved organic carbon and nitrogen in a Central European deciduous forest, Biogeochemistry, 55, 327-349, 2001.

Tiktak, A. and Bouten, W.: Soil water dynamics and long-term water balances of a Douglas fir stand in The Netherlands, J. Hydrol., 156, 265-283, 1994.

Vance, G. F. and David, M. B.: Dissolved organic carbon and sulfate sorption by spodosol mineral horizons, Soil Sci., 154, 136-144, 1992.
Van Dam, J. C.: Field-scale water flow and solute transport. SWAP model concepts, parameter estimation, and case studies, Dissertation, Wageningen University, 2000.

Van Dam, J. C., Huygen, J., Wesseling, J. G., et al: Simulation of water flow, solute transport and plant growth in the soil-wateratmosphere-plant environment, Theory of SWAP version 2.0. SC-DLO, Technical Document 45, Wageningen, The Netherlands, 1997.

Vandenbruwane, J., De Neve, S., Qualls, R. G., Salomez, J., and Hofman, G.: Optimization of dissolved organic nitrogen (DON) measurements in aqueous samples with high inorganic nitrogen concentrations, Sci. Total Environ., 386, 103-113, 2007a.

Vandenbruwane, J., De Neve, S., Qualls, R. G., Sleutel, S., and Hofman, G.: Comparison of different isotherm models for dissolved organic carbon (DOC) and nitrogen (DON) sorption to mineral soil, Geoderma, 139, 144-153, 2007b.

Vandenbruwane, J.: Dynamics of dissolved organic matter in forest ecosystems in Flanders, $\mathrm{PhD}$ dissertation, Ghent University, 2008.

van Genuchten, M. T.: A closed-form equation for predicting the hydraulic conductivity of unsaturated soils, Soil Sci. Soc. Am. J., 44, 892-898, 1980.

Zysset, M. and Berggren, D.: Retention and release of dissolved organic matter in podzol B horizons, Eur. J. Soil Sci., 52, 409421, 2001. 